\title{
Influence of Indigenous Mixotrophic Bacteria on Pyrite Surface Chemistry: Implications for Bioflotation
}

\author{
EDY SANWANI ${ }^{1}$, NUSLIA BAYANGKARA LAMANDHI ${ }^{1}$, HALIMATUL HUSNI $^{1}$, SITI \\ KHODIJAH CHAERUN ${ }^{1,2^{*}}$, FIKA ROFIEK MUFAKHIR ${ }^{3}$, AND WIDI ASTUTI ${ }^{3}$ \\ ${ }^{1}$ Department of Metallurgical Engineering, Faculty of Mining and Petroleum Engineering, Institut Teknologi Bandung, \\ Jalan Ganesha 10, Bandung 40132, Indonesia; \\ ${ }^{2}$ Geomicrobiology-Biomining \& Biocorrosion Laboratory, Microbial Culture Collection Laboratory, Biosciences and \\ Biotechnology Research Center (BBRC), Institut Teknologi Bandung, Jalan Ganesha 10, Bandung 40132, Indonesia; \\ ${ }^{3}$ Research Unit for Mineral Technology, Indonesian Institute of Sciences, \\ Jalan Ir. Sutami KM. 15, Tanjung Bintang, Lampung Selatan 35361, Indonesia.
}

\begin{abstract}
Given the low-cost and eco-friendly method, biotechnology has been widely utilized in industries as an alternative for physical and chemical processes, including in the biomining process (e.g., bioflotation and biobeneficiation). However, the use of biochemical reagent, which is selective for certain minerals, has not been well studied. This research was aimed to investigate the potential use of biosurfactant-producing mixotrophic bacteria as an alternative to chemical reagents during bioflotation and biobeneficiation process. Thirteen bacterial strains were investigated for their ability to produce biosurfactants and their effects on the surface properties of pyrite minerals. Bacteria-pyrite interaction experimental results showed that pyrite surface properties became more hydrophilic in the experimental systems inoculated with bacteria adapted with pyrite for $48 \mathrm{~h}$ than that without bacterial adaptation to pyrite, which was evidenced by the decrease in the contact angle of pyrite minerals by up to $50 \%$. This evidence was also confirmed by the highest emulsifying index value (51.6\%) attained during the bacteria-pyrite interaction. Hence, these bacteria can potentially be applied to selective flotation as pyrite depressants.
\end{abstract}

Key words: bioflotation, biosurfactants, contact angle, mixotrophic bacteria, pyrite

Dengan mempertimbangkan metode yang lebih murah dan ramah lingkungan, proses bioteknologi telah banyak digunakan dalam industri sebagai alternatif untuk proses fisika dan kimia, termasuk dalam proses biomining (seperti bioflotasi dan biobenefisiasi). Namun, penggunaan bioreagen yang selektif untuk mineral tertentu belum diteliti dengan baik. Penelitian ini bertujuan untuk menyelidiki potensi penggunaan bakteri mixotrofik penghasil biosurfaktan sebagai alternatif pengganti reagen kimia selama proses bioflotasi dan biobenefisiasi. Tiga belas strain bakteri diteliti karena kemampuan mereka dalam memproduksi biosurfaktan dan mempengaruhi sifat permukaan mineral pirit. Hasil percobaan interaksi bakteri-pirit menunjukkan bahwa sifat permukaan pirit menjadi lebih hidrofilik dalam sistem percobaan yang diinokulasi dengan bakteri yang diadaptasi dengan pirit selama 48 jam dibandingkan tanpa adaptasi bakteri terhadap pirit, yang dibuktikan dengan penurunan sudut kontak mineral pirit hingga 50\%. Bukti ini juga dikonfirmasi oleh nilai indeks pengemulsifikasi tertinggi $(51,6 \%)$ yang dicapai selama interaksi bakteri-pirit. Oleh karena itu, bakteri ini berpotensi dan dapat dijadikan sebagai alternatif bioreagen flotasi yang selektif sebagai depresan pirit.

Kata kunci: bakteri mixotrof, bioflotasi, biosurfaktan, pirit, sudut kontak

Nowadays, biotechnology is being developed in various industries in the world, especially in biomining and biobeneficiation. One of the interesting topics that has been widely discussed and developed is bioflotation in the last few decades. This is a major trend to carry out environmentally friendly mineral processing. Bioflotation is the process of separating valuable minerals from the gangue minerals by using bioflotation reagents, such as biosurfactants (Kyzas and Matis 2019). The use of biosurfactants as flotation

*Corresponding author: Phone: +62-22-2502239; Fax: +6222-2504209; Email: skchaerun@metallurgy.itb.ac.id bioreagents is a promising alternative to green flotation (bioflotation) because the biosurfactant is degradable, not toxic, and especially it brings out from the renewable resources (Lima et al. 2019; Silva et al. 2019).

Biosurfactants are produced from amphiphilic microorganisms consisting of hydrophilic and hydrophobic molecular groups that function to reduce surface tension (Almeida et al. 2019). Several studies have been conducted to show the use of biosurfactants as an alternative to environmentally friendly flotation reagents and continue developing to this day. Sanwani et al. used biosurfactants of the bacterium 
Pseudoclavibacter sp. to increase the hydrophobicity of chalcopyrite so that it can separate chalcopyrite from copper sulfide ores(Sanwani et al. 2017). The results of this study showed that the hydrophobicity of chalcopyrite mineral increased from 30 to 73 . Another study conducted by Merma et al. showed that the flotability of hematite increased as high as $90 \%$ based on the increase in biosurfactant concentration at acidic $\mathrm{pH}$ (Merma et al. 2018). In addition, there are still many studies conducted to study the effect of biosurfactants produced by microorganisms on the flotation process. These studies showed that the biosurfactant can separate minerals selectively (such as the separation of galena from sphalerite, chalcopyrite from pyrite, quartz from kaolinite, hematite from quartz, and many others) and can increase the flotability of valuable minerals (Hosseini et al. 2020; Huang et al. 2019; Kim et al. 2015; Consuegra et al. 2020; Martín et al. 2020).

Therefore, further research is needed to evaluate and optimize the use of biosurfactants in changing the surface properties of minerals so that later they can completely move flotation chemical reagents to be more environmentally friendly. This research was conducted to seek some alternative flotation reagents from the biosurfactants produced by various bacterial strains and their effects on the surface properties of pure pyrite. The results of this study may provide useful information on more environmentally friendly flotation reagents that are selective for certain minerals, namely pyrite.

\section{MATERIALS AND METHODS}

Selection of Potential Bacteria. Screening of bacteria that can produce biosurfactants is important to take on (Panjiar et al. 2017) because not all indigenous microbial isolates produce a lot of biosurfactants. Hence, it is necessary to select microorganisms properly to find out the microorganisms that produce optimum biosurfactants.

Bacterial Inoculation. Thirteen bacterial strains of the genera Bacillus spp., Paenibacillus sp., Pseudoclavibacter sp., Morganella sp., and Citrobacter spp. that had the ability to produce biosurfactants were evaluated to determine their potential as bioreagents in the flotation process. These pure bacterial strains were inoculated into a $250 \mathrm{ml}$ Erlenmeyer flask containing SKC-broth medium (molasses in seawater) that had been sterilized in an autoclave for $20 \mathrm{~min}$ at $121{ }^{\circ} \mathrm{C}$ and $1.5 \mathrm{~atm}$ (Arslan 2019). After that, the bacterial cultures were placed on a gyratory shaker and incubated for 60 hours under aerobic conditions by shaking at a rotation speed of 180 rpm. Biosurfactants produced by bacteria were observed by measuring the emulsifying activity index (EI), which was sampled periodically every 20 hours.

Emulsifying Index (EI) Measurement. A small amount of the incubated bacterial culture $(2 \mathrm{ml})$ was taken using a micropipette, then put into a test tube. A buffer solution $(2 \mathrm{ml})$ and coconut oil $(1 \mathrm{ml})$ were added to the test tube. After that, the solution in the test tube was stirred gradually for 2 minutes using a vortex at high speed-(Dikit et al. 2019; Campos et al. 2019). The optical density of the solution was measured using a UV-VIS spectrophotometer (recorded as A0), held out for 1 hour, and then the optical density of the solution was measured again (recorded as A1). The emulsifying index (EI) was calculated using the following formula:

$$
E I(\%)=\frac{A 1}{A 0} \times 100 \%
$$

Batch Experimental Procedure. Pure pyrite was used to study the interaction of bacteria with pyrite for evaluating pyrite surface properties. Pyrite was comminuted by the crushing and grinding tools to obtain a size fraction of $-75+45 \mu \mathrm{m}$ and passing $80 \%$ $\left(\mathrm{P}_{80}\right)$ at $75 \mu \mathrm{m}$. Fine particles are used to maximize the interaction between mineral particles and air bubbles during aeration and also to obtain the optimum recovery (Kim et al. 2017; La Vars 2018). The mineralogical characterization of pyrite minerals was analyzed by X-ray diffraction (XRD) shown in Figure 1 , showing the purity of pyrite of about $99.8 \%$. Before being used in the bacteria-pyrite interaction experiment, pure pyrite was washed with a low acid solution $\left(0.05 \mathrm{M} \mathrm{HNO}_{3}\right)$ and then washed with deionized water two times to ensure that the particles were not oxidized (Parthasarathy et al. 2014). The bacteria-pyrite interaction experiments were run in duplicate in $250 \mathrm{ml}$ Erlenmeyer flasks containing the SKC-broth medium for 48 hours. The flasks were then inoculated with bacteria (herein Citrobacter freundii strain SKC-4 or Bacillus altitudinis strain SKC/S-8), which were previously adapted to $20 \% \mathrm{w} / \mathrm{v}$ pure pyrite for 48 hours (designated "adapted"). In comparison, a control experiment was also conducted, which was identical to "adapted" but inoculated with bacteria without adaptation to pyrite (designated "nonadapted"). After 48 hours, the bacterial cultures were taken, and the separation of solid matter (herein pyrite) from solutions was performed using a centrifuge for 20 


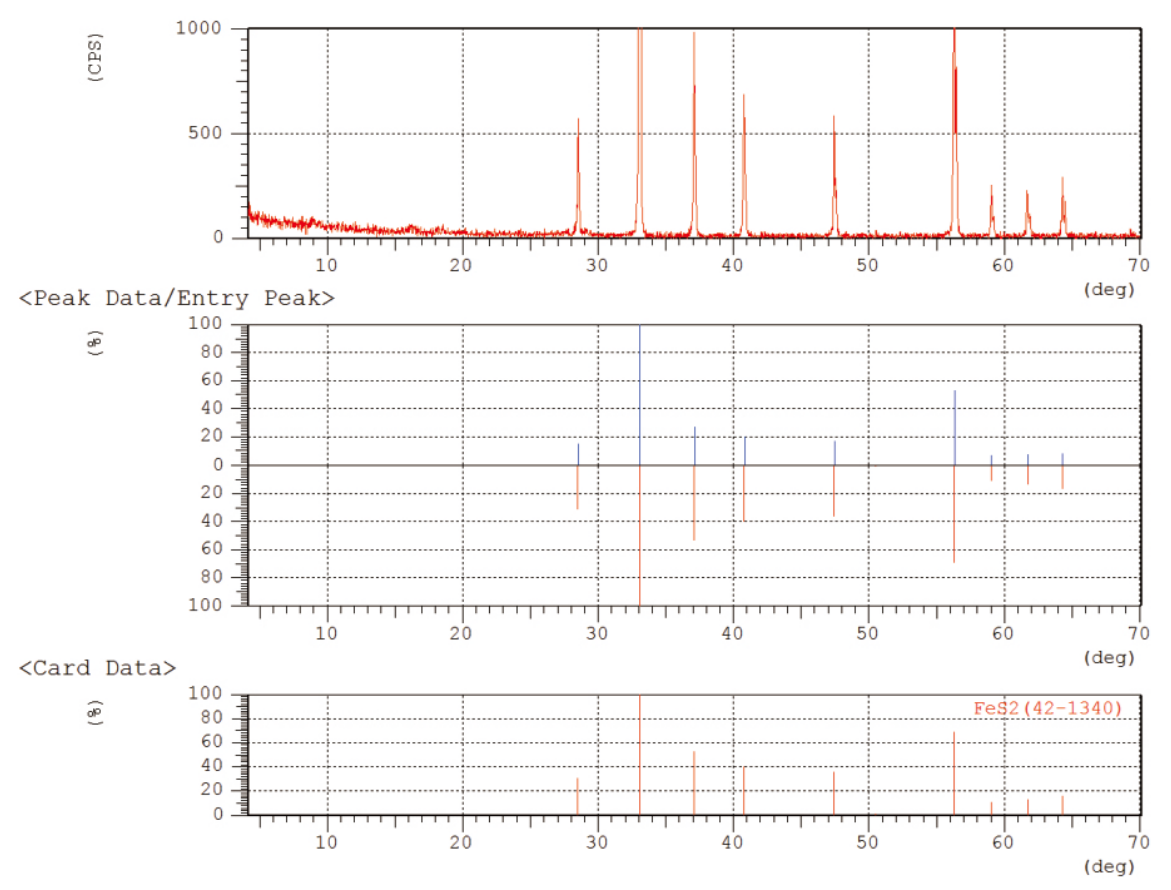

Fig 1 Characterization of pure pyrite used in this study using X-ray powder diffraction (XRD).

minutes. The separated solid was then put into the desiccator for 48 hours to obtain dried pyrite, and then a water drop test was performed to measure the contact angle of pyrite for evaluating its surface properties (Sharma 2001; Sharma et al. 2001). The images obtained from the water drop test were measured with the ImageJ application to find out the contact angle values(Williams et al. 2010).

\section{RESULTS}

Emulsifying Index (EI). Figure 2 shows the emulsifying index of all bacterial strains as a function of time. Emulsification index (EI) of four strains of the genus Bacillus (Bacillus velezensis strain $\mathrm{SKC} / \mathrm{S}-2$, Bacillus velezensis strain SKC/S-4, Bacillus velezensis strain SKC/S-5 and Bacillus nitratireducens strain SKC-2a) showed to increase from the onset of the incubation to 40 hours of incubation time. Two other species of the genus Bacillus, namely Bacillus altitudinis strain SKC/S-8 and Bacillus aryabhattai SKC-5, showed a decrease in EI after 20 hours, and a slight increase of EI was again observed after 40 hours. The exponential phase of almost all bacterial strains began after 20 hours of incubation time and followed by the stationary phase after 40 hours of incubation time. Correspondingly, bacteria of the genus Paenibacillus, namely Paenibacillus pasadenensis strain SKC/S-7 and the genus Morganella, namely
Morganella psychrotolerans strain SKC/S-6, showed a similar EI pattern to the genus Bacillus. However, Paenibacillus pasadenensis strain $\mathrm{SKC} / \mathrm{S}-3$ showed an increase in EI up to 40 hours of incubation and then increased significantly after 40 hours. Pseudoclavibacter sp. strain SKC/La and Citrobacter freundii strain SKC-4 showed a continuous increase from the beginning to the end of the incubation time, whereas Pseudoclavibacter sp. strain SKC/Ls and Citrobacter murliniae strain SKC-3 showed a decrease in EI after 20 hours of incubation time. In this study, Citrobacter freundii strain SKC-4 had the highest EI value of $51.64 \%$ and continued to rise up to the end of incubation time. This bacterium was hereafter used in subsequent experiments to evaluate the effect of bacteria on pyrite surface properties. In comparison, the bacterial strain that had the lowest EI value was also chosen for the next experiment, namely Bacillus altitudinis strain $\mathrm{SKC} / \mathrm{S}-8$.

Contact Angle Measurement for Pyrite Surface Properties. Contact angle measurement was performed to evaluate the effect of the biosurfactants generated by the two selected bacteria on pyrite surface properties (i.e., the hydrophobicity and hydrophilicity of pyrite). The pyrite contact angle values before and after interacting with bacteria were shown in Fig 3. Citrobacter freundii, which produced the highest biosurfactant, led to a pyrite surface contact angle value of $114^{\circ}$, which had a similar value to Bacillus altitudinis 


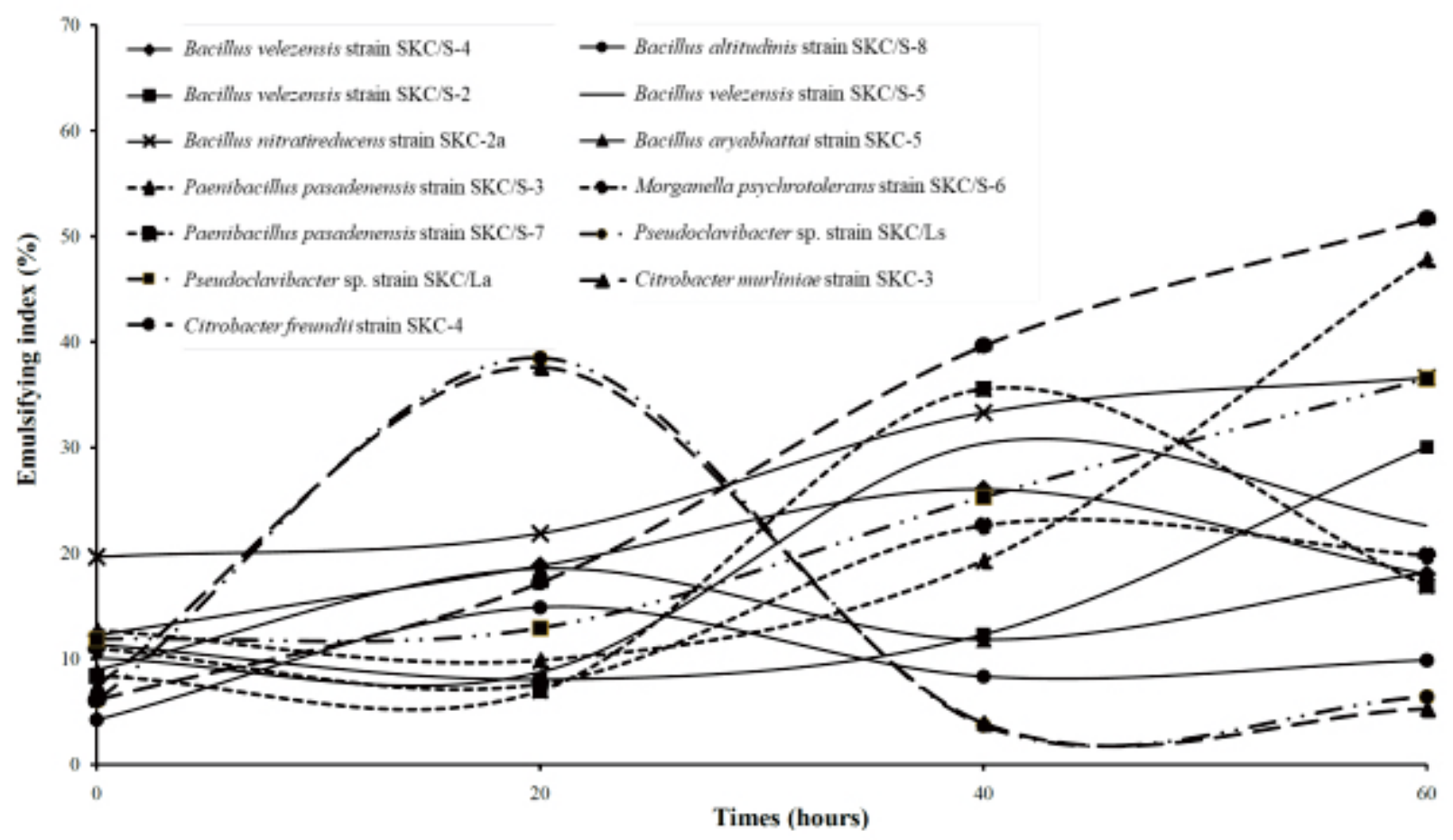

Fig 2 The emulsifying index of all bacterial strains as a function of time.
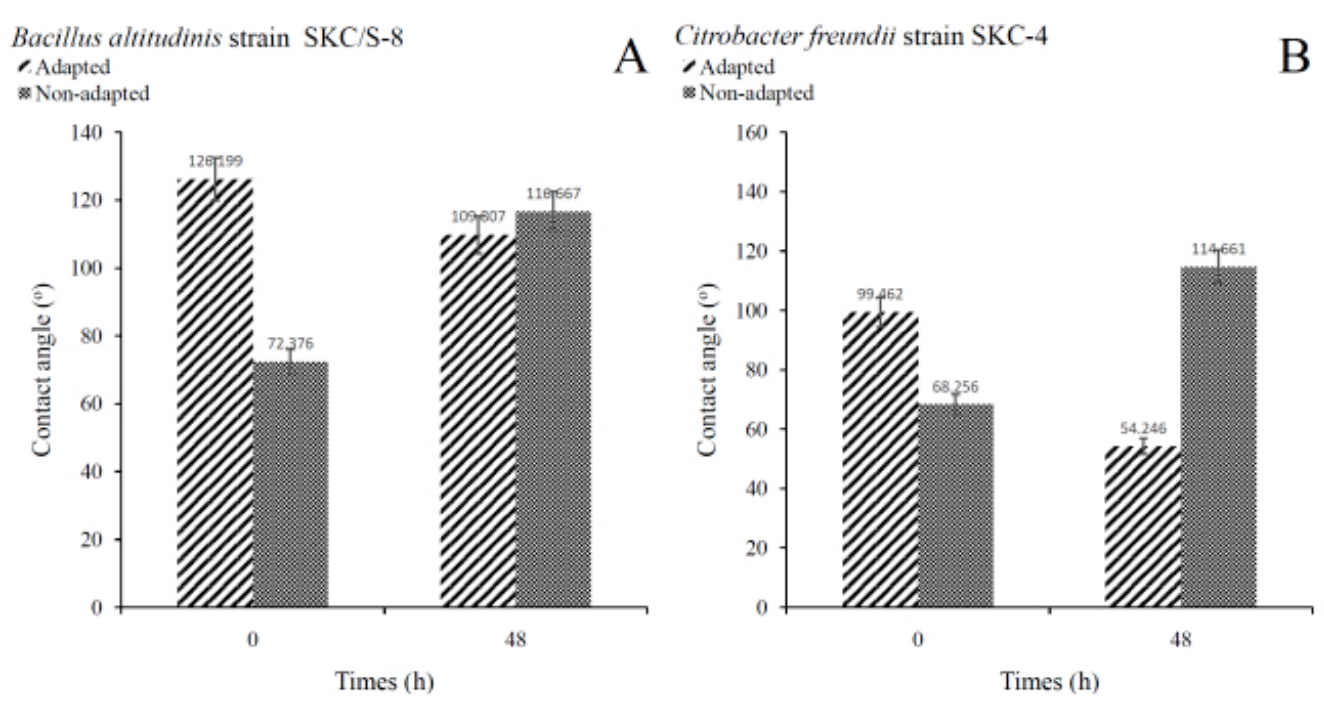

Fig 3 The contact angle values of pyrite before and after interacting with bacteria.

$\left(116^{\circ}\right)$. Both bacterial strains were not adapted to pyrite before the bacteria-pyrite interaction experiment, which showed an increase in contact angle after 48 hours of the experiment. Other experiments carried out by adapting both bacteria with pyrite for 48 hours during the bacteria-pyrite interaction showed different effects. After 48 hours, the experimental systems with Citrobacter freundii showed a decrease in contact angle value of up to $50 \%$. In contrast, the experimental system with Bacillus altitudinis did not have a significant effect.

\section{DISCUSSION}

Bioflotation process is one of the physicochemical methods that involve microorganisms in separating impurities from valuable minerals. This process utilizes certain mineral surface properties to attach to air bubbles and float together to the surface. The utilization of bacteria as bioreagent is needed in the separation of impurities from low-grade valuable minerals or complex minerals. The microorganisms produce biosurfactants, which can be an alternative to flotation 
bioreagents. Bacteria and their metabolic substances require contact time with certain minerals. When bacterial growth reaches an optimum time, the bacteria then release biosurfactants and form biofilms and then attach to certain mineral surfaces. Biosurfactants produced by bacteria depend on energy sources in their growth medium. Bacteria used in this study obtained their carbon source from molasses. Molasses has been reported to be the optimal carbon source for producing more biosurfactants compared to other carbon sources such as glucose and palm oil (Dikit et al. 2019). The amount of biosurfactant produced by bacteria is proportional to the value of the emulsifying index. Emulsifying indexes change over a certain period of time. This behavior seems to be influenced by bacterial growth, where bacterial growth experiences the lag phase, the exponential phase, and the stationary phase. In the exponential phase, bacteria grow significantly so that biosurfactant production increases. However, the most active bacteria occur in the stationary phase so that the amount of biosurfactant produced continues to increase (Abbasi et al. 2012; Amaral et al. 2006). Bacterial strains that show a high EI value suggest that the bacteria can produce more biosurfactants than other bacterial strains.

Bacteria that produce optimum biosurfactants were tested in a batch experiment that interacted with pyrite minerals. This experiment was carried out to evaluate the effect of bacteria and their biosurfactants on changes in the surface properties of pyrite minerals characterized by the contact angle values. The adaptation of bacteria with certain minerals at given incubation time, especially pyrite, in this study may allow biosurfactants to be produced by the bacterium to work more selectively against certain minerals. The results of this study are very prospective to be applied to the sulfide mineral bioflotation with pyrite as the gangue mineral. This result provides information on the use potential of this bacterium as depressants for pyrite minerals.

As conclusion, microorganisms can produce heteropolar biosurfactants that are hydrophobic as well as hydrophilic. The bacteria producing biosurfactants can be more useful for the metallurgy industry, one of which is as an alternative to environmentally friendly flotation reagents. However, not all microorganisms produce biosurfactants that have the same ability, so that it is necessary to choose the appropriate microorganisms to be utilized in a particular process. In this study, Citrobacter freundii can produce more biosurfactants than other bacterial strains. The biosurfactants produced by the bacterium are also beneficial, thus decreasing the hydrophobicity of pyrite minerals or increasing the hydrophilicity. The biosurfactant generated by this bacterium is expected to be an alternative flotation reagent that can be used as a depressant for pyrite minerals.

\section{ACKNOWLEDGEMENT}

We acknowledge all the members of Geomicrobiology-Biomining \& Biocorrosion Laboratory and Microbial Culture Collection Laboratory, Biosciences and Biotechnology Research Center (BBRC), Institut Teknologi Bandung for their cooperation and assistance. This work was supported by a grant from the Han An Hua Foundation to SKC.

\section{REFERENCES}

Abbasi H, Hamedi MM, Lotfabad TB, Zahiri HS, Sharafi H, Masoomi F, Moosavi-movahedi AA, Ortiz A, Amanlou M, Noghabi KA. 2012. Biosurfactant-producing bacterium, Pseudomonas aeruginosa MA01 isolated from spoiled apples: Physicochemical and structural characteristics of isolated biosurfactant. J Biosci Bioeng. 113(2):211-219. doi: 10.1016/j.jbiosc.2011.10.002.

Almeida DG, Luna JM, Silva IA, Silva EJ, Santos VA, Brasileiro PPF, Sarubbo LA. 2019. Biosurfactant from Pseudomonas cepacia CCT 6659 as alternative collector in dissolved air flotation system for soap and detergent industry effluent treatment. Chem Eng Trans. 74:361-366. doi: 10.3303/CET1974061.

Amaral PFF, Silva JM, Lehocky M, Barros-timmons AMV, Coelho MAZ, Marrucho IM, Coutinho JAP. 2006. Production and characterization of a bioemulsifier from Yarrowia lipolytica. Process Biochem. 41(8): 1894-1898. doi: 10.1016/j.procbio.2006.03.029.

Arslan V. 2019. Comparison of the effects of Aspergillus niger and Aspergillus ficuum on the removal of impurities in feldspar by bio-beneficiation. Appl Biochem Biotechnol. 189:437-447. doi: 10.1007/s12010-019-03029-7.

Campos JM, Stamford TLM, Sarubbo LA. 2019. Characterization and application of a biosurfactant isolated from Candida utilis in salad dressings. Biodegradation. 30(4):313-324. doi: 10.1007/s10532019-09877-8

Consuegra GL, Kutschke S, Rudolph M, Pollmann K. 2020. Halophilic bacteria as potential pyrite bio-depressants in Cu-Mo bioflotation. Miner Eng. 145:106062. doi: 10.1016/j.mineng.2019.106062.

Dikit P, Maneerat S, Saimmai A. 2019. The effective emulsifying property of biosurfactant - producing Marinobacter hydrocarbonoclasticus ST1 obtained from palm oil contaminated sites. Appl Biochem Microbiol. 
55: 615-625. doi: 10.1134/S0003683819060061.

Hosseini MR, Sadeghieh SM, Azizinia MR, Tabatabaei SH. 2020. Biological separation of quartz from kaolinite using Bacillus licheniformis. Sep Sci Technol. 55(11): 2061-2071. doi: 10.1080/01496395.2019.1617738.

Huang B, Lai H, Deng J, Xu H, Fan G. 2019. Study on the interaction between galena and sphalerite during grinding based on the migration of surface components. ACS Omega. 4(7):12489-12497. doi: 10.1021/acsomega.9b01173.

Kim G, Choi J, Silva RA, Song Y, Kim H. 2017. Feasibility of bench-scale selective bioflotation of copper oxide minerals using Rhodococcus opacus. Hydrometallurgy. 168: 94-102. doi: 10.1016/j.hydromet.2016.06.029.

Kim G, Park K, Choi J, Gomez-flores A, Han Y, Choi SQ, Kim H. 2015. Bioflotation of malachite using different growth phases of Rhodococcus opacus: Effect of bacterial shape on detachment by shear flow. Int J Miner Process. 143:98-104. doi: 10.1016/j.minpro.2015.09.012.

Kyzas GZ, Matis KA. 2019. The Flotation process can go green. Processes. 7:1-14. doi: 10.3390/pr7030138.

La Vars S. 2018. The impact of microorganisms on the surface of pyrite : Implications for bioflotation. Doctoral Thesis, Flinders University.

Lima MT, Groß M, Simon M, Schreiber S, Gradzielski M. 2019. Surface and aggregation properties of a plant-oil derived biosurfactant. Colloids Surf B. 174:521-527. doi: 10.1016/j.colsurfb.2018.11.055.

Martín FS, Kracht W, Vargas T, Rudolph M. 2020. Mechanisms of pyrite biodepression with Acidithiobacillus ferrooxidans in seawater flotation. Miner Eng. 145:106067. doi: 10.1016/j.mineng.2019.106067.

Merma AG, Oliv CAC, Torem ML, Santos BF. 2018.
Comparison study of hematite bioflotation by $R$. erythropolis and its biosurfactant: Experiments and neural network modeling. Chem Eng Trans. 65:439-444. doi: 10.3303/CET1865074.

Panjiar N, Sachan SG, Sachan A. 2017. Biosurfactants: A multifunctional microbial metabolite. Microb Appl. 2:213-229. doi: 10.1007/978-3-319-52669-0 12.

Parthasarathy H, Baltrus JP, Dzombak DA, Karamalidis AK. 2014. A method for preparation and cleaning of uniformly sized arsenopyrite particles. Geochem Trans. 15(1):1-7. doi: 10.1186/s12932-014-0014-9.

Sanwani E, Mirahati RZ, Chaerun SK. 2017. Recovery of copper from pyritic copper ores using a biosurfactantproducing mixotrophic bacterium as bioflotation reagent. Solid State Phenom. 262:181-184. doi: 10.4028/www.scientific.net/SSP.262.181.

Sharma PK. 2001. Surface studies relevant to microbial adhesion and bioflotation of sulphide minerals. Doctoral Thesis, Luleå University of Technology.

Sharma PK, Rao KH, Forssberg KSE, Natarajan KA. 2001. Surface chemical characterisation of Paenibacillus polymyxa before and after adaptation to sulfide minerals. Int J Miner Process. 62(1-4):3-25. doi: 10.1016/S03017516(00)00043-0.

Silva EJ, Silva IA, Brasileiro PPF, Correa PF, Almeida DG, Rufino RD, Luna JM, Santos VA, Sarubbo LA. 2019. Treatment of oily effluent using a low-cost biosurfactant in a flotation system. Biodegradation. 30(4):335-350. doi: 10.1007/s10532-019-09881-y.

Williams DL, Kuhn AT, Amann MA, Hausinger MB, Konarik MM, Nesselrode EI. 2010. Computerised measurement of contact angles. Galvanotechnik. 101(11): 2502. 